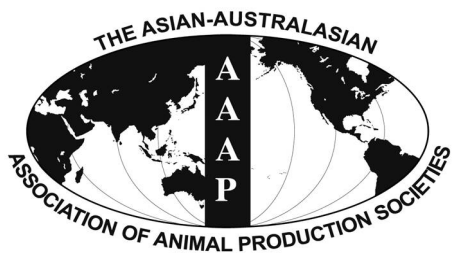

Open Access

Asian Australas. J. Anim. Sci.

Vol. 29, No. 4 : 530-538 April 2016

http://dx.doi.org/10.5713/ajas.15.0673

Www.ajas.info

pISSN 1011-2367 elSSN 1976-5517

\title{
Characteristics of Wet Distillers Grains on In vitro Ruminal Fermentation and Its Effects on Performance and Carcass Characteristics of Finishing Hanwoo Steers
}

\author{
Gyu Chul Ahn ${ }^{\text {a }}$, Hyung Jun Kwak ${ }^{\mathrm{a}}$, Young Kyoon $\mathrm{Oh}^{1}$, Yoo Kyung Lee', \\ Sun Sik Jang ${ }^{1}$, Sang Suk Lee ${ }^{2}$, and Keun Kyu Park* \\ Department of Animal Science and Technology, Konkuk University, Seoul 143-701, Korea
}

\begin{abstract}
Two experiments were conducted to determine the nutrient composition, in vitro ruminal ammonia concentrations and $\mathrm{pH}$ of wet distillers grains (WDG, produced from tapioca $70 \%$ and rice $30 \%$ ) and to evaluate dietary effects of fermented total mixed ration (TMR) using WDG on the performance, blood metabolites and carcass characteristics of Hanwoo steers from mid fattening to slaughter. In Exp. I, average dry matter (DM), crude protein, ether extract, crude fiber, ash, neutral detergent fiber, acid detergent fiber, and nitrogen free extract of seven WDG samples from an ethanol plant with different sampling dates were $19.9 \%, 24.8 \%, 3.8 \%, 21.8 \%$, $8.87 \%, 60.3 \%, 34.5 \%$, and $40.7 \%$ (DM basis), respectively. For in vitro ammonia concentrations and $\mathrm{pH}$, each sample was assigned to 7 incubation times $(0,4,8,12,24,48$, and $72 \mathrm{~h})$. Linear increase was observed between 12 and $48 \mathrm{~h}$ for ammonia concentrations, but final ammonia concentrations $(72 \mathrm{~h})$ were not significantly different among WDG samples and fermentation patterns of WDG samples showed similar tendency. In vitro $\mathrm{pH}$ varied among treatments from 0 to $24 \mathrm{~h}$, but were not different statistically after $48 \mathrm{~h}$. In Exp. II, 45 Hanwoo steers of 23 months ( $641 \pm 123 \mathrm{~kg}$ ) from mid fattening period to slaughter (248 days) were randomly divided into three groups of 15 pens each (five repetitions/each treatment) and assigned to one of three dietary treatments; i) Control (TMR), ii) WDG 15 (TMR containing $15 \%$ of WDG, as fed basis) and iii) WDG 28 (TMR containing $28 \%$ of WDG, as fed basis). The body weight (BW), ADG, and feed conversion ratio (FCR) of control and WDG 15 and 28 during 248 days were $760.8,740.1$, and $765.5 \mathrm{~kg}$, and $0.50,0.50$, and $0.52 \mathrm{~kg} / \mathrm{d}$, and 18.6, 17.6, and 17.1, respectively. The dry matter intake (DMI) $(\mathrm{kg} / \mathrm{d})$ of control $(9.11)$ was higher $(\mathrm{p}<0.05)$ than WDG treatments (WDG 15\%, 8.57; 28\%, 8.70). Nevertheless, DMI did not affect BW, ADG, and FCR of Hanwoo finishing steers. Blood metabolites were in normal ranges and were not different among treatments except the albumin concentration. In carcass characteristics, WDG $15(30 \%)$ showed higher frequency of A-carcass yield grade than WDG $28(15 \%)$ and control (7\%), and WDG 28 (61\%) showed higher frequency of $1^{++}$and $1^{+}$-carcass quality grade than WDG $15(40 \%)$ and control $(60 \%)$. In conclusion, using WDG up to $28 \%$ in TMR did not show any negative effect on the performance and blood metabolites, and improved carcass quality of Hanwoo steers. Therefore, WDG can be a useful feed ingredient for Hanwoo steers in mid-fattening period to slaughter. (Key Words: Hanwoo, Steers, Total Mixed Ration, Distillers By-products, Wet Distillers Grains, Carcass Characteristics)
\end{abstract}

\section{INTRODUCTION}

The cost of rearing Hanwoo cattle is not constant due to

\footnotetext{
* Corresponding Author: Keun Kyu Park. Tel: +82-2-450-3661, Fax: +82-2-455-1044, E-mail: kkpark@konkuk.ac.kr

${ }^{1}$ National Institute of Animal Science, RDA, Jeonju 331-808, Korea.

2 Department of Animal Science and Technology, Sunchon National University, Sunchon 540-950, Korea.

${ }^{a}$ These two authors contributed equally to this work.

Submitted Aug. 12, 2015; Revised Sept. 29, 2015; Accepted Nov. 4, 2015
}

the unstable feed cost in South Korea. Feed cost takes more than half of the whole production cost of Hanwoo cattle in South Korea (Statistics Korea, 2015). Because of the high feeding cost, it is economical to partially replace feed ingredients with by-products, and the greater the addition of by-products in feeds can result in the most economical production costs.

Distillers by-products can be a good source of protein and energy in cattle diets (Rouse and Trenkle, 1980). Distillers grains (DG) are a cereal coproduct of the distillation process by a broader definition (Liu, 2011) and 
have been used widely for ruminants' feed ingredients in the last decade. Distillers grains can be classified into three different kinds as follows, wet distillers grains (WDG), dried distillers grains (DDG) and dried distillers grains with solubles (DDGS) by drying process. In DG, fiber, protein and fat are concentrated approximately 3 -fold in distillers grains when starch is fermented to produce ethanol (Klopfenstein et al., 2008). Thus, DG have been shown to be an excellent protein source for growing ruminants (Waller et al., 1980). Feeding DDG and DDGS as a protein source has been presumed to be too expensive (Ham et al., 1994), however, using WDG may change these economics.

During the past decade, mostly in the United States, the bioethanol industry has experienced a dramatic growth, DDGS production have been increased, thus the studies to evaluate DDGS as a protein source have been widely conducted and the source of ethanol producing by-products was mostly DDGS from wheat and corn (Shurson and Noll, 2005). However, limited data are available about the usefulness of WDG from tapioca and rice, the most popular ingredients for producing ethanol in South Korea. Unlike the case of the United States, just four ethanol plants out of ten in South Korea have drying facilities (in 2012) for producing DG, thus the greatest amount of DG produced by ethanol plants is WDG, and the lowest amount of DG is DDGS.

Among the type of DG, WDG has some advantages as a feed ingredient for animals. WDG is more economical than DDGS and DDG. Due to the absence of drying process of WDG, the price of WDG (KRW $25 / \mathrm{kg}$ ) is lower than DDG (KRW 280/kg) and DDGS (KRW 270/kg) in South Korea. Drying DG is an expensive process and may account for more than $40 \%$ of the energy cost incurred by the alcohol plant (Stock and Klopfenstein, 1982). Furthermore, WDG can have nutritional advantages over other DG if managed correctly, and supply less heat damaged protein due to the absence of drying process (Dooley et al., 2008). The effects of heat from drying on the nutritional value of DDGS had been debated (Van Soest, 1989; Weiss et al., 1989).

However, WDG has a typical moisture content of $75 \%$ to $80 \%$, (Abrams et al., 1983, Kim et al., 2015). Due to the high moisture content, it cannot be economically transported to great distances from the ethanol plant and it can be contaminated easily, particularly in hot weather. Thus, it must be utilized as a livestock feed within a few days after separated from whole stillage (Abrams et al., 1983). Co-ensiling WDG with other feed sources such as a total mixed ration (TMR) can be a safe way to store WDG for long periods of time (Buckmaster et al., 2008) and WDG can be a useful feed ingredient for cattle farms near the ethanol plant, particularly feeding self-formulating TMR.

Waldo et al. (2009) reported that DDGS from wheat and corn was an excellent protein source for ruminants, but there are little data available concerning the characteristics and nutritional quality of WDG, particularly from tapioca and rice. Kim et al. (2015) reported that WDG from tapioca and rice can be an useful feed source for rearing Hanwoo steers from initial to mid-fattening period and can be used up to $20 \%$ (as fed basis) in the feeds. However, there is no information available investigating mid-fattening period to slaughter, carcass characteristics and beef quality of Hanwoo steers feeding WDG more than 20\%. Therefore, the purposes of this study were to i) investigate ruminal fermentation characteristics of WDG from tapioca $70 \%$ and rice $30 \%$, and ii) evaluate the ability of WDG as a feed ingredient of TMR for Hanwoo steers in mid-fattening period to slaughter and meat quality.

\section{MATERIALS AND METHODS}

\section{Exp. 1. Chemical analyses and in vitro ruminal fermentation of WDG}

Preparation of WDG: WDG samples were obtained from a commercial ethanol plant (located in Gyeongsangnam-do, South Korea) producing for alcoholic liquors and medical disinfectants. Seven WDG Samples (A to G; Tables 2, 3, and 4) were collected from the ethanol plant at different dates, from November 2012 to August 2014 (11/19/2012, 11/07/2013, 12/06/2013, 04/15/2014, 04/23/2014, 06/11/2014, and 08/19/2014).

Chemical analysis: Seven-WDG samples were dried in a forced-air oven for over 24 hours. Drying temperature for WDG samples was $55^{\circ} \mathrm{C}$, which was relatively low temperature to prevent browning reaction of protein. After drying, samples were ground through $1 \mathrm{~mm}$ screen using a Wiley mill (Model 4, Thomas Scientific, Swedesboro, NJ, USA). Prepared WDG samples after drying and milling were used for chemical analyses and in vitro trial.

Dry matter (DM), crude protein (CP), ether extract (EE, crude fat), crude fiber (CF), and ash contents were determined according to AOAC official methods (1999), and neutral detergent fiber (NDF, ash-free) and acid detergent fiber (ADF, ash-free) contents were analyzed according to the procedure of Van Soest et al. (1991). Nitrogen free extract (NFE) value were calculated as follows, $\mathrm{NFE}=\% \mathrm{DM}-(\% \mathrm{EE}+\% \mathrm{CP}+\%$ ash $+\% \mathrm{CF})$.

In vitro ruminal fermentation study: In vitro ruminal fermentation was conducted to determine the ammonia release and $\mathrm{pH}$ of WDG at each sampling time. The substrates used in in vitro study were seven-WDG from an ethanol plant at different dates (A to G). A Tilley and Terry (1963) procedure was performed for in vitro trial. Centrifuge tubes $(50 \mathrm{~mL} ; 7$ samples $\times 7$ incubation times $\times$ triplicate) with fermentation gas release hole (diameter, 0.5 $\mathrm{mm}$ ) were used for in vitro trial. Composited ruminal fluid 
was obtained from three ruminally fistulated $(120 \mathrm{~mm}$; Bar Diamond INC, Parma, ID, USA) Hanwoo steers (612 kg of average body weight [BW]) fed 8:2 forage:concentrate diet. Forage diet was rice straw with free access to water and mineral block (Rincal block, Daehan New Pham, Seoul, Korea; provided following nutrients per kg: I, $150 \mathrm{mg}$; Mn, $200 \mathrm{mg}$; S, 4,000 mg; Co, 100 mg; Fe, 2,000 mg; Zn, 100 mg; Ni, 50 mg; Cu, 100 mg; Mg, 3,000 mg; Ca, 2,000 mg; $\mathrm{Se}, 40 \mu \mathrm{g} ; \mathrm{NaCl}, 380 \mathrm{~g}$ ). The concentrate contained (DM basis) ground corn $(1.9 \%)$, ground wheat $(30.0 \%)$, wheat bran $(11.8 \%)$, corn gluten feed $(12.0 \%)$, rice bran $(5.0 \%)$, salt $(0.5 \%)$, molasses $(6.5 \%)$, cottonseed hull $(2.0 \%)$, ammonium chloride $(0.15 \%)$, corn flour $(6.0 \%)$, palm kernel meal $(5.0 \%)$, copra meal $(10.0 \%)$, rapeseed meal $(3.6 \%)$, limestone $(3.0 \%)$, porphyry $(1.0 \%)$, vitaminmineral premix $(0.15 \%$; Grobic-DC, Bayer Health Care, Leverkusen, Germany; each $\mathrm{kg}$ of DM of the vitamin and mineral mixture contained as follows: Vit. A, 2,650,000 IU; Vit. $\mathrm{D}_{3}, 530,000 \mathrm{IU}$; Vit. E, 1,050 IU; niacin, 10,000 mg; Mn, 4,400 mg; Zn, 4,400 mg; Fe, 13,200 mg; Cu, 2,200 mg; I, 440 mg; Co, 440 mg).

Ruminal fluid was obtained before morning feeding and filtered through eight layers of cheese cloth and the container filled with $\mathrm{CO}_{2}$-saturated gas for $5 \mathrm{~min}$ to maintain anaerobic condition. After $\mathrm{CO}_{2}$ gas injection, ruminal fluid was transported immediately to the laboratory in a pre-warmed thermos and thermal box maintained at $39^{\circ} \mathrm{C}$. Approximately $0.5 \mathrm{~g}$ of substrate (WDG) was weighed and placed in triplicate $50 \mathrm{~mL}$ centrifuge tubes and inoculum was prepared by diluting the rumen fluid with the McDougall's buffer (McDougall et al., 1948) in a 1:1 (vol:vol) ratio. After adding inoculum $(40 \mathrm{~mL})$ to the centrifuge tube, $\mathrm{CO}_{2}$-saturated gas was injected for five seconds to maintain an anaerobic condition in the fermentation tube. The tubes were incubated in a shaking water bath with constant oscillation $(80 \mathrm{rpm})$ at $39^{\circ} \mathrm{C}$ for six incubation times $(4,8,12,24,48$, and $72 \mathrm{~h}$; 0 time samples were not placed into the shaking water bath).

After each incubation time, $\mathrm{pH}$ of whole culture was measured immediately using a $\mathrm{pH}$ meter ( $\mathrm{pH}$ meter 430 , Corning, One Riverfront Plaza, New York, USA), and centrifuged at 25,000 rpm for $20 \mathrm{~min}$. The supernatant fraction was transferred into the $1 \mathrm{~mL}$ micro-centrifuge tube and stored frozen at deep freezer $\left(-20^{\circ} \mathrm{C}\right)$. Ammonia $\left(\mathrm{NH}_{3}-\right.$ $\mathrm{N})$ concentrations were analyzed as described by Chaney and Marbach (1962) using enzyme-linked immunosorbent assay (UV-detector, $630 \mathrm{~nm}$; Microplate reader Gen5, Biotek Instruments INC, Winooski, VT, USA).

Statistical analysis: Data obtained from in vitro ruminal fermentation experiments were subjected to statistical analysis using the general linear model (GLM) procedure of SAS (Ver. 9.03, SAS Institute, 2002). All data were analyzed by analysis of variance and Duncan's multiple range test was used to determine significant differences $(p<0.01$ and 0.05$)$ among the treatments within each classification.

\section{Exp. 2. Effects of dietary WDG on performance of finishing Hanwoo steers}

Experimental design: Forty five Hanwoo steers of 23 months age (average BW, 641 $\pm 123 \mathrm{~kg}$ ) were randomly divided into three groups of 15 pens each (five repetitions per each treatment) and assigned to one of the three dietary treatments for 248 days (mid-fattening period to slaughter). The experiment was conducted from April to December, 2014. Treatments in this study were as follows; i) Control (TMR; no WDG), ii) WDG-15 (TMR containing 15\% of WDG, as fed basis) and iii) WDG-28 (TMR containing 28\% of WDG, as fed basis). The ingredients and chemical composition of experimental diets for each treatment are shown in Table 1.

The steers were housed in sawdust bedding-surfaced pens $(3$ steers $/$ pen; $4.0 \mathrm{~m}$ wide $\times 8.0 \mathrm{~m}$ length $=32 \mathrm{~m} /$ pen; $10.7 \mathrm{~m}^{2} /$ steer; $4.0 \mathrm{~m}$ wide linear feed bunk space; the water supply system was at the opposite side of feed bunk) with a

Table 1. Ingredients and chemical composition of TMR

\begin{tabular}{|c|c|c|c|}
\hline \multirow{2}{*}{ Items } & \multirow{2}{*}{ Control } & \multicolumn{2}{|c|}{$\mathrm{WDG}^{1}$} \\
\hline & & 15 & 28 \\
\hline \multicolumn{4}{|l|}{ Ingredients (as fed basis, \%) } \\
\hline WDG & 0.00 & 15.64 & 27.90 \\
\hline Corn gluten feed & 7.00 & 7.85 & 10.20 \\
\hline Molasses & 4.01 & 4.02 & 4.02 \\
\hline Cotton seed & 0.00 & 1.52 & 3.00 \\
\hline Wheat bran & 15.43 & 17.29 & 14.50 \\
\hline Corn flaked & 40.00 & 33.00 & 30.00 \\
\hline Barley straw & 8.78 & 8.78 & 8.50 \\
\hline Water & 22.90 & 10.00 & 0.00 \\
\hline Vitamin, mineral premix & 0.10 & 0.10 & 0.10 \\
\hline Limestone & 0.80 & 0.82 & 0.80 \\
\hline Salt & 0.45 & 0.45 & 0.45 \\
\hline Humic soil & 0.53 & 0.53 & 0.53 \\
\hline Total & 100 & 100 & 100 \\
\hline \multicolumn{4}{|c|}{ Chemical composition (DM basis, \%) } \\
\hline $\mathrm{DM}$ & 68.4 & 69.0 & 71.5 \\
\hline $\mathrm{CP}$ & 11.1 & 11.6 & 12.0 \\
\hline $\mathrm{EE}$ & 2.9 & 3.3 & 3.6 \\
\hline $\mathrm{CF}$ & 9.9 & 10.8 & 11.0 \\
\hline Ash & 7.5 & 7.8 & 7.8 \\
\hline NDF & 37.0 & 40.5 & 41.4 \\
\hline $\mathrm{ADF}$ & 12.7 & 15.7 & 16.3 \\
\hline NFE & 69.8 & 66.5 & 66.7 \\
\hline TDN & 78.5 & 76.5 & 77.2 \\
\hline
\end{tabular}

TMR, total mixed rations; WDG, wet distillers grains; DM, dry matter; $\mathrm{CP}$, crude protein; EE, ether extract; $\mathrm{CF}$, crude fiber; NDF, neutral detergent fiber; ADF, acid detergent fiber; NFE, nitrogen free extract; TDN, total digestible nutrients.

${ }^{1}$ WDG 15 , WDG $15 \%$, as fed basis; WDG 28 , WDG $28 \%$, as fed basis. 
blowing fan $(2 \mathrm{~m} / \mathrm{s}$; diameter $=1,025 \mathrm{~mm}, 790 \mathrm{rpm}$; DVN1007, Dongkun Industrial Co., Ltd, Incheon, South Korea) and were marked with numbered tag in their ear. Feeds were offered equally at 06:00 and 18:00 $\mathrm{h}$ on daily basis (7 $\mathrm{kg} / \mathrm{meal} / \mathrm{steer} ; 14 \mathrm{~kg} / \mathrm{d} / \mathrm{steer}$ ), and refused feed was removed every day and weighed back every week to determine daily intake and feed conversion ratio (FCR; feed/gain). They were allowed to access fresh water and mineral block without any restriction during the whole experimental period. Steers were weighed at initial (0 day), first mid (98 day), second mid (162 day) and final days (248 day) using a digital scale (Digital indicator Cl-200A, CAS, Seoul, South Korea) before morning feeding of whole experimental days.

Chemical analysis and calculations of experimental feeds: Chemical composition (DM, CP, EE, CF, ash, NDF, $\mathrm{ADF}$, and NFE) of experimental feeds were determined as the same procedure as in Exp. 1. FCR, total digestible nutrients (TDN) values of experimental feeds were calculated as follows: i) $\mathrm{FCR}=$ dry matter intake $/ \mathrm{BW}, \mathrm{kg} / \mathrm{kg}$. ii) $\mathrm{TDN}=0.93 \times \mathrm{CP}+0.92 \times(1+\mathrm{EE}-\mathrm{ash}-\mathrm{CP}-\mathrm{NDF})+0.75 \times$ $(\mathrm{NDF}-\mathrm{ADL}) \times\left(1-\mathrm{ADL}^{2 / 3} / \mathrm{NDF}^{2 / 3}\right)($ Conrad et al., 1984).

Blood metabolites: Blood from steers were collected on 162 day of experimental days. Blood samples were analyzed for alcohol, glucose, aspartate transaminase (AST), alanine transaminase (ALT), albumin, total cholesterol, triglyceride, low density lipoprotein cholesterol (LDL cholesterol), high density lipoprotein cholesterol (HDL cholesterol), creatinine and blood urea nitrogen (BUN) using an auto-chemistry analyzer (Modular Analytics, Roche, Basel, Switzerland).

Carcass characteristics and beef quality: After finishing in vivo trial, steers were transferred to slaughter house (located in Jeollanam-do, South Korea) after 24 hours fasting. Carcass characteristics were measured by the Korean Carcass Grading Standard (2010). The items of carcass characteristics measured in this study were cold carcass weight $(\mathrm{kg})$, yield traits (back fat thickness, mm; $M$, longissimus dorci area at the 13th rib interface, $\mathrm{cm}^{2}$; Yield index; Yield grade, converted to numeric value: grade $\mathrm{A}=1$,
$\mathrm{B}=2$, and $\mathrm{C}=3$; Frequencies of carcass yield grade, A:B:C, \%) and quality traits (marbling score, $9=$ the most abundant, 1 = devoid; meat color, 7 = dark red, $1=$ bright; fat color, 7 = yellowish, 1 = white; texture, 3 = coarse, $1=$ fine; maturity, 9 = mature, 1 = youthful; quality grade, converted to numeric value, grade $1^{++}=1,1^{+}=2,1=3,2=$ 4 , and $3=5$; frequencies of carcass quality grade, $1^{++}: 1^{+}: 1: 2, \%$; dressing percentage, $\%$ ).

Statistical analysis: Data obtained from the in vivo trial (BW, ADG, DMI, FCR, blood metabolites and carcass characteristics) were subjected to statistical analysis using the GLM procedure of SAS (SAS Institute, 2002; version 9.03). Data were analyzed by analysis of variance and Duncan's multiple range tests were used to determine significant differences $(\mathrm{p}<0.01$ and 0.05$)$ among treatments.

\section{RESULTS AND DISCUSSIONS}

\section{Exp. 1. Chemical analysis and in vitro ruminal fermentation of WDG}

Chemical analysis of experimental feed: The chemical composition of WDG from an ethanol plant with different sampling dates are presented in Table 2. Average DM concentration of WDG was $19.9 \%$. Because WDG have high moisture content, fermented TMR would be suitable for using WDG as a feed ingredient. In preparing a TMR, $\mathrm{Xu}$ et al. (2007) added water to adjust moisture content up to $55 \%$. In our study, WDG 28 did not need an additional water supply into TMR (Table 1), thus, using WDG for fermented TMR can simplify TMR production. Besides, according to Stock and Klopfenstein (1982), drying WDG is expensive and may account for more than $40 \%$ of the energy costs incurred by the alcohol plant, thus WDG is more economical than DDG and DDGS, except for difficulties of transport and handling. In South Korea, the price of WDG (KRW 25/kg) is less than one-tenth of DDG (KRW 280/kg) and DDGS (KRW 270/kg).

According to Waldo et al. (2009), DG is a good protein source for growing and finishing cattle. In this study, CP

Table 2. Chemical composition of wet distillers grains from an ethanol plant with different sampling dates

\begin{tabular}{|c|c|c|c|c|c|c|c|c|}
\hline Items & $\mathrm{A}^{1}$ & B & C & D & E & $\mathrm{F}$ & G & Mean \\
\hline \multirow[t]{2}{*}{ DM (\%) } & 19.79 & 19.90 & 21.25 & 20.03 & 19.06 & 18.87 & 20.34 & 19.89 \\
\hline & & & & ---- \% & ------ינ & 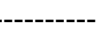 & & ----- \\
\hline $\mathrm{CP}$ & 29.27 & 26.52 & 30.25 & 23.97 & 21.66 & 22.55 & 19.64 & 24.84 \\
\hline $\mathrm{EE}$ & 4.21 & 3.46 & 2.40 & 4.85 & 4.44 & 4.08 & 3.38 & 3.83 \\
\hline $\mathrm{CF}$ & 19.72 & 17.31 & 20.87 & 23.37 & 23.24 & 24.42 & 23.70 & 21.80 \\
\hline Ash & 10.20 & 4.93 & 8.17 & 9.49 & 10.93 & 9.75 & 8.65 & 8.87 \\
\hline NDF & 59.55 & 59.47 & 61.23 & 58.49 & 57.72 & 59.00 & 66.75 & 60.32 \\
\hline $\mathrm{ADF}$ & 29.72 & 30.66 & 31.91 & 35.08 & 38.23 & 36.25 & 39.40 & 34.46 \\
\hline NFE & 36.59 & 47.78 & 38.30 & 38.32 & 39.73 & 39.21 & 44.63 & 40.65 \\
\hline
\end{tabular}

DM, dry matter; CP, crude protein; EE, ether extract; CF, crude fiber; NDF, neutral detergent fiber; ADF, acid detergent fiber; NFE, nitrogen free extract.

${ }^{1}$ A to G, replication with different sampling dates during November 2012 and August 2014 (2012/11/19, 2013/11/07, 2013/12/06, 2014/04/15, 2014/04/23, 2014/06/11, and 2014/08/19). 
Table 3. Effects of wet distiller's grains at different sampling dates on in vitro ruminal ammonia concentrations

\begin{tabular}{|c|c|c|c|c|c|c|c|c|}
\hline Time (h) & $\mathrm{A}^{1}$ & B & $\mathrm{C}$ & D & E & $\mathrm{F}$ & G & SEM \\
\hline & - & $=$ & & $-\mathrm{mg} /$ & & 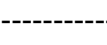 & ------- & \\
\hline 0 & 73.2 & 74.0 & 77.0 & 69.5 & 71.5 & 76.9 & 71.5 & 2.32 \\
\hline 4 & $105.7^{\mathrm{b}}$ & $83.7^{\mathrm{d}}$ & $117.1^{\mathrm{a}}$ & $86.2^{\mathrm{d}}$ & $82.3^{\mathrm{d}}$ & $71.2^{\mathrm{e}}$ & $97.3^{\mathrm{c}}$ & 2.53 \\
\hline 8 & $123.4^{\mathrm{a}}$ & $67.8^{\mathrm{b}}$ & $125.9^{\mathrm{a}}$ & $67.3^{\mathrm{b}}$ & $64.2^{\mathrm{b}}$ & $67.3^{\mathrm{b}}$ & $82.5^{\mathrm{b}}$ & 5.87 \\
\hline 12 & $117.4^{\mathrm{a}}$ & $78.1^{\mathrm{b}}$ & $125.2^{\mathrm{a}}$ & $65.3^{\mathrm{c}}$ & $60.1^{\mathrm{c}}$ & $58.1^{\mathrm{c}}$ & $86.2^{\mathrm{b}}$ & 3.25 \\
\hline 24 & $186.4^{\mathrm{ab}}$ & $186.0^{\mathrm{ab}}$ & $205.0^{\mathrm{ab}}$ & $229.1^{\mathrm{a}}$ & $206.4^{\mathrm{ab}}$ & $165.5^{\mathrm{b}}$ & $185.9^{\mathrm{ab}}$ & 15.54 \\
\hline 48 & $374.5^{\mathrm{bc}}$ & $372.6^{b c}$ & $448.5^{\mathrm{a}}$ & $395.2^{\mathrm{b}}$ & $342.1^{\mathrm{c}}$ & $351.1^{\mathrm{bc}}$ & $334.2^{\mathrm{c}}$ & 14.96 \\
\hline 72 & 450.9 & 464.3 & 489.0 & 472.3 & 410.2 & 410.7 & 441.9 & 26.96 \\
\hline
\end{tabular}

SEM, standard error of means.

${ }^{1}$ A to G, replications with different sampling dates during November 2012 and August 2014 (2012/11/19, 2013/11/07, 2013/12/06, 2014/04/15, 2014/04/23, 2014/06/11, and 2014/08/19).

${ }^{\mathrm{a}-\mathrm{e}}$ Means within a row without a common superscript letter differ $(\mathrm{p}<0.05)$.

concentrations of WDG from different sampling dates ranged from $19.6 \%$ to $30.3 \%$ (DM basis), and average CP concentrations of WDG were $24.8 \%$ (DM basis). Kim et al. (2015) reported that CP concentrations of WDG (tapioca and rice, $7: 3$ ) from seven ethanol plant ranged from $26.5 \%$ to $40.4 \%$ (DM basis), thus showed higher CP concentrations than our study. The concentration of CP for WDG depends on the proportion and type of grain sources. Although a typical ratio of tapioca and rice is known as 7:3 in ethanol producing companies of Korea, the actual ratio is confidential and can be varied by several factors such as cost and availability of grain sources, stockpile of old rice, and other situations in a company. For example, Quinn et al. (2011) reported average CP concentration of WDG (from corn and sorghum, 7:3) was 30.0\% (DM basis). May et al. (2010) reported that WDG showed greater CP concentration from 9:1 blend of corn and sorghum grains (CP, 33.4\%) than 7:3 blend of corn and sorghum grains (CP, 30.0\%).

In vitro ammonia concentrations and $p H$ of $W D G$ : The changes of in vitro ammonia concentrations and $\mathrm{pH}$ of
WDG from an ethanol plant with different sampling dates are shown in Table 3, Figure 1 and Table 4, respectively. There are limited data available about in vitro ruminal ammonia concentrations and $\mathrm{pH}$ of feeds using WDG. In addition, there were no data available about the in vitro ammonia concentrations and $\mathrm{pH}$ of WDG itself. WDG can be a useful protein source for ruminants (Kim et al., 2015), thus in vitro ammonia concentrations of WDG itself may be useful data.

In this study, in vitro ammonia concentrations of WDG at $0 \mathrm{~h}$ ranged from 69.3 to $77.0 \mathrm{mg} / \mathrm{L}$ and there were no differences among WDG samples. Ammonia concentrations at $4 \mathrm{~h}$ after incubation ranged from 71.2 (F) to $117.1 \mathrm{mg} / \mathrm{L}$ (C). During 4 to $48 \mathrm{~h}$ after incubation, ammonia concentrations of WDG were different $(p<0.05)$ among samples, but fermentation patterns of WDG samples showed similar tendency. A dramatic increase was observed between 12 and $48 \mathrm{~h}$, but final ammonia concentrations were not significantly different among WDG samples. Final ammonia concentrations at $72 \mathrm{~h}$ after incubation were

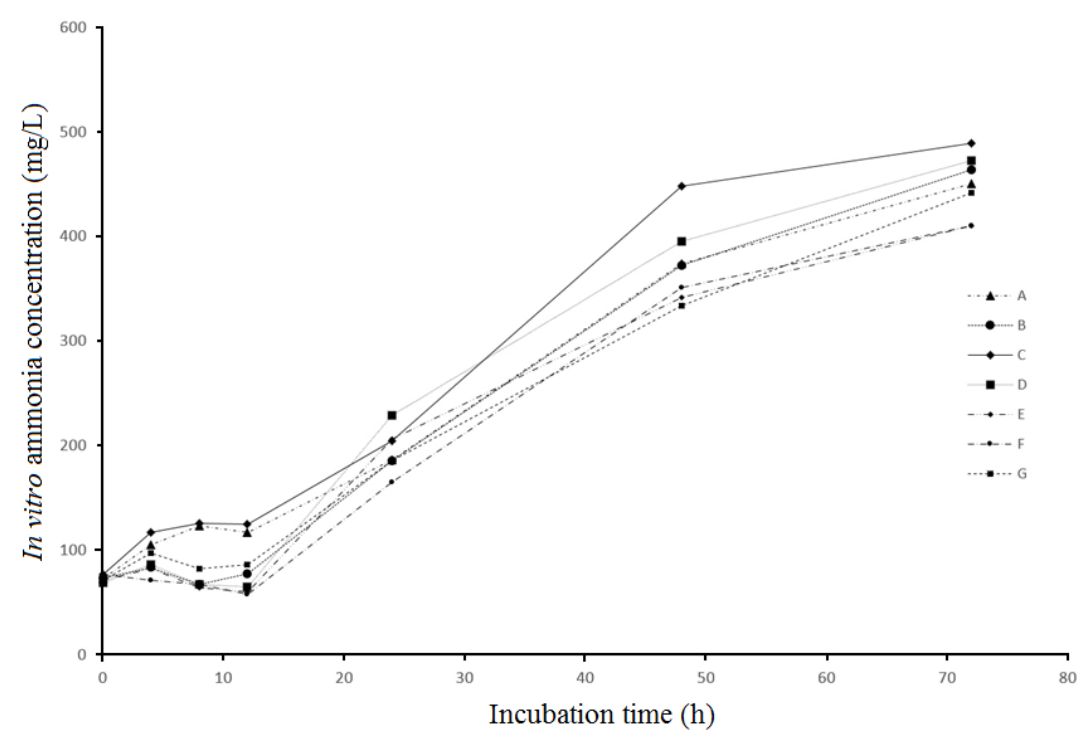

Figure 1. Changes in in vitro ammonia concentrations $(\mathrm{mg} / \mathrm{L})$ of wet distiller's grains at different sampling dates. 
Table 4. Effects of wet distiller's grains at different sampling dates on in vitro $\mathrm{pH}$

\begin{tabular}{|c|c|c|c|c|c|c|c|c|}
\hline Time (h) & $\mathrm{A}^{1}$ & B & $\mathrm{C}$ & D & E & $\mathrm{F}$ & G & SEM \\
\hline 0 & $6.74^{\mathrm{a}}$ & $6.68^{\mathrm{c}}$ & $6.72^{\mathrm{ab}}$ & $6.64^{d}$ & $6.64^{\mathrm{d}}$ & $6.71^{\mathrm{abc}}$ & $6.70^{\mathrm{bc}}$ & 0.01 \\
\hline 4 & $6.95^{\mathrm{a}}$ & $6.86^{\mathrm{b}}$ & $6.87^{\mathrm{b}}$ & $6.74^{c}$ & $6.71^{\mathrm{c}}$ & $6.74^{\mathrm{c}}$ & $6.82^{\mathrm{b}}$ & 0.02 \\
\hline 8 & $6.83^{\mathrm{a}}$ & $6.58^{\mathrm{abc}}$ & $6.73^{\mathrm{ab}}$ & $6.46^{\mathrm{bc}}$ & $6.43^{c}$ & $6.54^{\mathrm{bc}}$ & $6.61^{\mathrm{abc}}$ & 0.09 \\
\hline 12 & $6.63^{\mathrm{a}}$ & $6.51^{\mathrm{ab}}$ & $6.57^{\mathrm{a}}$ & $6.29^{b}$ & $6.43^{\mathrm{ab}}$ & $6.46^{\mathrm{ab}}$ & $6.54^{\mathrm{ab}}$ & 0.08 \\
\hline 24 & $6.89^{\mathrm{ab}}$ & $6.60^{\mathrm{b}}$ & $6.97^{\mathrm{a}}$ & $6.59^{\mathrm{b}}$ & $6.63^{\mathrm{ab}}$ & $6.64^{\mathrm{ab}}$ & $6.69^{\mathrm{ab}}$ & 0.10 \\
\hline 48 & 6.80 & 6.68 & 6.62 & 6.67 & 6.61 & 6.54 & 6.70 & 0.08 \\
\hline 72 & 7.14 & 7.08 & 7.25 & 6.77 & 6.94 & 7.24 & 6.64 & 0.25 \\
\hline
\end{tabular}

SEM, standard error of means.

${ }^{1}$ A to G, replication with different sampling dates during November 2012 and August 2014 (2012/11/19, 2013/11/07, 2013/12/06, 2014/04/15, 2014/04/23, 2014/06/11, and 2014/08/19)

${ }^{\mathrm{a}-\mathrm{d}}$ Means within a row without a common superscript letter differ $(\mathrm{p}<0.05)$.

ranged from 410.2 to $489.0 \mathrm{mg} / \mathrm{L}$. Although the concentration of $\mathrm{CP}$ in WDG samples was varied by samples $(19.6 \%$ to $30.3 \%$, average $24.8 \%$ ), WDG were mostly fermented from 24 to $48 \mathrm{~h}$ of incubation time. Therefore, when using WDG from tapioca and rice for feed ingredients, consideration of these fermentation characteristics is needed.

In vitro $\mathrm{pH}$ of $\mathrm{WDG}$ showed variations $(\mathrm{p}<0.05)$ at 0 to $24 \mathrm{~h}$ incubation time among samples. On the other hand, $\mathrm{pH}$ at 48 and $72 \mathrm{~h}$ did not show any statistical difference among WDG samples.

Exp. 2. Effects of dietary WDG on performance of finishing Hanwoo steers and beef quality

WDG on performance of finishing Hanwoo steers: The BW, ADG, DMI, and FCR of control and WDG treatments are shown in Table 5. Initial (0 day) BW of control, WDG 15 and 28 were $634.6,615.3$, and $643.3 \mathrm{~kg}$, respectively. Final (248 days) BW of control, WDG 15 and 28 were $760.8,740.1$, and $765.5 \mathrm{~kg}$, respectively, and were not different among treatments. In addition, there were no statistical differences among treatments during the middle of experimental days (98 and 162 days).

The ADG of Hanwoo steers were 0.50, 0.50, and 0.52 $\mathrm{kg} / \mathrm{d}$ for control, WDG 15 and 28, and were not different statistically during the whole experimental period. Kim et al. (2015) reported that ADG of Hanwoo steers during the initial to mid-fattening period were $0.74 \mathrm{~kg} / \mathrm{d}$ for WDG $20 \%$ (as fed basis). In this study, ADG was lower than 0.50 after $99 \mathrm{~d}$, because the Hanwoo steers were at the final fattening period. According to the Korean Feeding Standard for Hanwoo (NIAS, 2012), ADG of Hanwoo steers is decreased below $0.6 \mathrm{~kg} / \mathrm{d}$ at the finishing of fattening period.

The DMI of Hanwoo steers at 0 to 98 days of experimental days were higher $(\mathrm{p}<0.03)$ in control $(9.89$ $\mathrm{kg} / \mathrm{d})$ than WDG $15(9.19 \mathrm{~kg} / \mathrm{d})$ and $28 \%(9.33 \mathrm{~kg} / \mathrm{d})$, but were not different between WDG treatments. At 99 to 162 of experimental days, DMI of Hanwoo steers were higher $(\mathrm{p}<0.05)$ in control $(8.47 \mathrm{~kg} / \mathrm{d})$ than WDG treatments (average $7.47 \mathrm{~kg} / \mathrm{d}$ ). DMI from 163 to 248 experimental days did not show any statistical difference. Consequently, DMI of whole experimental days were higher $(\mathrm{p}<0.05)$ in control $(9.11 \mathrm{~kg} / \mathrm{d})$ than WDG treatments (WDG 15, 8.57 $\mathrm{kg} / \mathrm{d} ; 28 \%, 8.70 \mathrm{~kg} / \mathrm{d})$. Nevertheless, DMI did not affect BW, ADG, and FCR of Hanwoo steers.

FCR of steers were 18.6, 17.6, and 17.1 for control and WDG 15 and 28, respectively, and did not show any significant difference among treatments throughout the whole experimental period. As an in vivo on-farm trial results, using WDG in feeds did not show negative effects on BW, ADG, and FCR of Hanwoo steers. Therefore, WDG

Table 5. Effects of dietary WDG for TMR ingredients on BW, ADG, DMI, and FCR of Hanwoo steers

\begin{tabular}{lcccc}
\hline \multirow{2}{*}{ Items } & \multirow{2}{*}{ Control } & \multicolumn{2}{c}{ WDG $^{1}$} & \multirow{2}{*}{ SEM } \\
\cline { 3 - 4 } & & 15 & 28 & \\
\hline BW $(\mathrm{kg})$ & & & & \\
$0 \mathrm{~d}$ & 634.6 & 615.3 & 643.3 & 20.6 \\
$98 \mathrm{~d}$ & 698.3 & 680.6 & 711.1 & 23.8 \\
$162 \mathrm{~d}$ & 722.9 & 705.5 & 736.6 & 24.5 \\
$248 \mathrm{~d}$ & 760.8 & 740.1 & 765.5 & 24.0 \\
$\mathrm{ADG}(\mathrm{kg} / \mathrm{d})$ & & & & \\
0 to $98 \mathrm{~d}$ & 0.65 & 0.67 & 0.69 & 0.07 \\
99 to $162 \mathrm{~d}$ & 0.39 & 0.39 & 0.40 & 0.03 \\
163 to $248 \mathrm{~d}$ & 0.43 & 0.40 & 0.39 & 0.04 \\
0 to end & 0.50 & 0.50 & 0.52 & 0.04 \\
DMI $(\mathrm{kg} / \mathrm{d})$ & & & & \\
0 to $98 \mathrm{~d}$ & $9.89^{\mathrm{a}}$ & $9.19^{\mathrm{b}}$ & $9.33^{\mathrm{ab}}$ & 0.14 \\
99 to $162 \mathrm{~d}$ & $8.47^{\mathrm{a}}$ & $7.50^{\mathrm{b}}$ & $7.44^{\mathrm{b}}$ & 0.24 \\
163 to $248 \mathrm{~d}$ & 8.98 & 8.70 & 8.55 & 0.17 \\
0 to end & $9.11^{\mathrm{a}}$ & $8.57^{\mathrm{b}}$ & $8.70^{\mathrm{b}}$ & 0.11 \\
FCR & & & & \\
0 to $98 \mathrm{~d}$ & 15.8 & 14.3 & 14.2 & 1.50 \\
99 to $162 \mathrm{~d}$ & 22.4 & 20.1 & 19.2 & 1.77 \\
163 to $248 \mathrm{~d}$ & 21.6 & 23.0 & 22.1 & 1.92 \\
0 to end & 18.6 & 17.6 & 17.1 & 1.18 \\
\hline
\end{tabular}

WDG, wet distiller's grains; TMR, total mixed rations; BW, body weight; ADG, average daily gain; DMI, dry matter intake; FCR, feed conversion ratio (feed intake/kg gain); SEM, standard error of means.

${ }^{1}$ WDG 15 , WDG $15 \%$, as fed basis; WDG 28 , WDG $28 \%$, as fed basis.

a-b Means within a row without a common superscript letter differ $(\mathrm{p}<0.05)$. 
can be used up to $28 \%$ in the TMR for Hanwoo steers at mid-fattening to slaughter. According to Owens et al. (1998) and Klopfenstein et al. (2008), the incidence of subacute acidosis may be decreased when DG are included as more than $20 \%$ of feedlot diets, because of increased fiber, protein and decreased starch in DG. However, subacute acidosis was not observed in our study.

Blood metabolites: Blood metabolites in this study are shown in Table 6. There was no alcohol detected from blood metabolites, thus using WDG for feed ingredient is safe from toxic effect of alcohol. According to Kim et al. (2015), despite of DG produced from alcohol processing, WDG had no alcohol content. Alcohol concentrations over $5 \%$ in the diet reduced ruminal fermentation of beef cattle (Itabashi et al., 1991).

Albumin concentrations of control and WDG treatments were lower $(\mathrm{p}<0.05)$ in WDG $28 \%(3.7 \mathrm{~g} / \mathrm{dL})$ than control $(4.0 \mathrm{~g} / \mathrm{dL})$ and WDG $15(3.9 \mathrm{~g} / \mathrm{dL})$. Total plasma proteinconsists primarily of albumin and globulins, thus it can be used as an indicator of protein status (Huntington et al., 2001; Scharf et al., 2010). Nevertheless, albumin concentrations did not affect in vivo parameters: BW, ADG, DMI, and FCR of Hanwoo steers. All blood metabolites, such as alcohol, albumin, AST, ALT, total cholesterol, triglyceride, LDL cholesterol, HDL cholesterol, creatinine, BUN values were in normal ranges.

Carcass characteristics and beef quality: Carcass characteristics and beef quality of Hanwoo steers fed WDG feed are presented in Table 7. Twenty-four $\mathrm{h}$ after slaughter the carcass was weighted to measure the cooling and shrinkage losses. Cold carcass weight of control $(462.5 \mathrm{~kg})$
Table 6. Effects of dietary wet distiller's grains for total mixed rations ingredients on blood metabolites of Hanwoo steers

\begin{tabular}{lcccc}
\hline \multirow{2}{*}{ Items } & \multirow{2}{*}{ Control } & \multicolumn{2}{c}{ WDG $^{1}$} & \multirow{2}{*}{ SEM } \\
\cline { 3 - 4 } & & 15 & 28 & \\
\hline Alcohol (\%) & ND & ND & ND & - \\
Albumin (g/dL) & $4.0^{\mathrm{a}}$ & $3.9^{\mathrm{a}}$ & $3.7^{\mathrm{b}}$ & 0.03 \\
AST (U/L) & 70.9 & 62.1 & 60.7 & 4.34 \\
ALT (U/L) & 20.0 & 20.8 & 21.4 & 0.77 \\
Glucose (mg/dL) & 79.6 & 75.4 & 78.6 & 2.10 \\
Total cholesterol (mg/dL) & 134.3 & 125.2 & 144.5 & 7.90 \\
Triglyceride (mg/dL) & 29.0 & 27.4 & 23.9 & 2.31 \\
LDL cholesterol (mg/dL) & 23.5 & 22.7 & 27.4 & 1.66 \\
HDL cholesterol (mg/dL) & 109.3 & 106.5 & 116.1 & 4.34 \\
Creatinine (mg/dL) & 1.4 & 1.5 & 1.5 & 0.06 \\
BUN (mg/dL) & 13.0 & 12.0 & 13.5 & 0.95 \\
\hline WDG w
\end{tabular}

WDG, wet distiller's grains; SEM, standard error of means; ND, not detected; AST, aspartate transaminase; ALT, alanine transaminase; LDL, low density lipoprotein cholesterol; HDL, high density lipoprotein cholesterol; BUN, blood urea nitrogen.

${ }^{1}$ WDG 15 , WDG $15 \%$, as fed basis; WDG 28 , WDG $28 \%$, as fed basis.

a-b Means within a row without a common superscript letter differ $(\mathrm{p}<0.05)$.

and WDG treatment $(15 \%, 439.1 \mathrm{~kg} ; 28 \%, 463.2 \mathrm{~kg}) \mathrm{did}$ not show any statistical difference.

Adding WDG in TMR did not affect yield traits, such as back fat thickness, M. longissimus dorci area and yield index. Converted numeric values of yield grade tended to be lower in WDG 15 (1.87) than control (2.47) and WDG 28 (2.27). However, WDG 15 showed the highest percentage of A-grade frequencies (30\%) for carcass yield grade (A:B:C, \%) and WDG 28 showed $15 \%$ of A-grade. Control

Table 7. Effects of dietary wet distiller's grains for total mixed ration ingredients on carcass characteristics of Hanwoo steers

\begin{tabular}{|c|c|c|c|c|}
\hline \multirow{2}{*}{ Items } & \multirow{2}{*}{ Control } & \multicolumn{2}{|c|}{$\mathrm{WDG}^{1}$} & \multirow{2}{*}{ SEM } \\
\hline & & 15 & 28 & \\
\hline Cold carcass weight $(\mathrm{kg})$ & 462.5 & 439.1 & 463.2 & 17.93 \\
\hline \multicolumn{5}{|l|}{ Yield traits } \\
\hline Back fat thickness (mm) & 14.67 & 11.43 & 14.53 & 1.12 \\
\hline M. longissimus dorci area $\left(\mathrm{cm}^{2}\right)$ & 91.20 & 91.10 & 95.25 & 2.17 \\
\hline Yield index & 63.00 & 65.57 & 63.59 & 0.97 \\
\hline Yield grade $^{2}$ & 2.467 & 1.867 & 2.267 & 0.23 \\
\hline Frequencies of carcass yield grade, A:B:C (\%) & $7: 40: 53$ & $30: 40: 30$ & $15: 46: 39$ & - \\
\hline \multicolumn{5}{|l|}{ Quality traits } \\
\hline Marbling score ${ }^{3}$ & 5.467 & 4.900 & 6.233 & 0.46 \\
\hline Meat color ${ }^{4}$ & 4.733 & 4.733 & 4.400 & 0.17 \\
\hline Fat color ${ }^{5}$ & 3.266 & 3.000 & 3.067 & 0.10 \\
\hline Texture $^{6}$ & 1.133 & 1.267 & 1.000 & 0.09 \\
\hline Maturity $^{7}$ & 2.000 & 2.000 & 2.100 & 0.03 \\
\hline Quality grade $^{8}$ & 2.333 & 2.833 & 2.067 & 0.26 \\
\hline Frequencies of carcass quality grade, $1^{++}: 1^{+}: 1: 2(\%)$ & $13: 47: 33: 7$ & $0: 40: 50: 10$ & $23: 38.5: 38.5: 0$ & - \\
\hline Dressing percentage $(\%)$ & 60.78 & 59.27 & 60.47 & 0.60 \\
\hline
\end{tabular}

WDG, wet distiller's grains; SEM, standard error of means.

${ }^{1}$ WDG 15 , WDG $15 \%$, as fed basis; WDG 28 , WDG $28 \%$, as fed basis.

${ }^{2}$ Converted to numeric value: grade $\mathrm{A}=1, \mathrm{~B}=2$, and $\mathrm{C}=3 \cdot{ }^{3} 9=$ the most abundant, $1=$ devoid. ${ }^{4} 7=$ dark red, $1=$ bright.

${ }^{5} 7=$ yellowish, $1=$ white. ${ }^{6} 3=$ coarse, $1=$ fine. ${ }^{7} 9=$ mature, $1=$ youthful. ${ }^{8}$ Converted to numeric value: grade $1^{++}=1,1^{+}=2,1=3,2=4$ and $3=5$. 
showed only $7 \%$ of A-grade, thus WDG treatments had higher frequencies of A-grade than control. High frequencies of A grade in WDG 15 (11.4) may be influenced by the lower back fat thickness compared to control (14.7) and WDG 28 (14.5), although significant differences among treatments were not detected.

Quality traits in this study were not statistically different on marbling score, meat color, fat color, texture, maturity and dressing percentage. Converted numeric values of quality grade were 2.07 for WDG 28, 2.33 for control and 2.83 for WDG 15, in ascending order, but were not statistically different. Frequencies of carcass quality grade of $1^{++}$-grade were $0 \%$ for WDG $15,13 \%$ for control and $23 \%$ for WDG 28. Low frequencies of $1^{++}$-grade for WDG 15 seems to be associated with low back fat thickness. According to Lee et al. (2012), marbling score was increased with the increase of backfat thickness in Hanwoo cows and steers, but only small relationship existed between marbling score and backfat thickness in Hanwoo bulls.

In conclusion of carcass characteristics, using WDG in fermented TMR up to $28 \%$ has an effect of enhancing carcass yield grade and carcass quality grade of Hanwoo steers above the control. Based on our results, for maximizing frequencies of A-carcass yield grade of Hanwoo steers, WDG 15 would be recommended instead of WDG 28. On the other hand, WDG 28 would be a better choice for enhancing frequencies of more than $1^{+}$-carcass quality grades $\left(1^{++}\right.$and $1^{+}$grade) than WDG 15 . Although the reason is unclear, it may be a result from lower NFE of WDG 28 than WDG 15 , caused by slightly higher CP, EE, and CF of WDG 28 compared with WDG 15 and control. Owens et al. (1998) reported that when DG was increased in the diet, $\mathrm{CP}$ and $\mathrm{CF}$ were increased, in contrast, starch was decreased in the diet. In South Korea, carcass quality grade is much more important than carcass yield grade to determine the price of beef, thus using WDG up to $28 \%$ in the diets may enhance the benefits of rearing Hanwoo steers.

\section{CONCLUSION}

WDG produced from tapioca and rice (7:3) can be a useful feed ingredient for ruminants, considering CP concentrations, in vitro ruminal ammonia concentration and $\mathrm{pH}$. The use of WDG up to $28 \%$ (as fed basis) in TMR did not show any negative effect on the performance and blood metabolites, and improved carcass quality of Hanwoo steers in the mid- to final fattening period. Therefore, WDG can be a useful feed ingredient for Hanwoo steers in midfattening period to slaughter.

\section{CONFLICT OF INTEREST}

We certify that there is no conflict of interest with any financial organization regarding the material discussed in the manuscript.

\section{ACKNOWLEDGMENTS}

This study was supported by 'Cooperative Research Program for Agriculture Science \& Technology Development (Project No. PJ009156)' Rural Development Administration, Republic of Korea.

\section{REFERENCES}

Abrams, S. M., T. J. Klopfenstein, R. A. Stock, R. A. Britton, and M. L. Nelson. 1983. Preservation of wet distillers grains and its value as a protein source for growing ruminants. J. Anim. Sci. 57:729-738

AOAC. 1999. Official Methods of Analysis. 16th ed. Association Official Analytical Chemists, Arlington, VA, USA.

Buckmaster, D. R., P. G. Gunn, S. L. Lake, R. P. Lemenager, and M. C. Claeys. 2008. Co-ensiling of wet distillers grains. Presentation no. 083645. American Society of Agricultural and Biological Engineers Meeting, Providence, RI, USA.

Chaney, A. L. and E. P. Marbach. 1962. Modified reagents for determination of urea and ammonia. Clin. Chem. 8:130-132.

Conrad, H. R., W. P. Weiss, W. O. Odwongo, and W. L. Shockey. 1984. Estimating net energy lactation from components of cell solubles and cell walls. J. Dairy Sci. 67:427-436.

Dooley, F. J., M. Cox, and L. Cox. 2008. Distillers grain handbook: A guide for Indiana producers to using DDGS for animal feed. A report for the Indiana Corn Marketing Council. http://incorn.org/index.php?option=com_content\&task=view\& id=43 Accessed July 17, 2008.

Ham, G. A., R. A. Stock, T. J. Klopfenstein, E. M. Larson, D. H. Shain, and R. P. Huffman. 1994. Wet corn distillers byproducts compared with dried corn distillers grains with solubles as a source of protein and energy for ruminants. J. Anim. Sci. 72:3246-3257.

Huntington, G., M. Poore, B. Hopkins, and J. Spears. 2001. Effect of ruminal protein degradability on growth and $\mathrm{N}$ metabolism in growing beef steers. J. Anim. Sci. 79:533-541.

Itabashi, H., T. Kobashi, A. Takenaka, and M. Matsumoto. 1991. Influence of Ethanol on ruminal microbes and Fermentation pattern hydrogenation of unsaturated fatty acids, and Meat quality of beef cattle. Proceedings of the 3rd International Symposium on the Nutrition Herbivores, Penang, Malaysis. pp. 73.

Kim, I. Y., G. C. Ahn, H. J. Kwak, Y. K. Lee, Y. K. Oh, S. S. Lee, J. H. Kim, and K. K. Park. 2015. Characteristics of wet and dried distillers grains on in vitro ruminal fermentation and effects of dietary wet distillers grains on performance of Hanwoo steers. Asian Australas. J. Anim. Sci. 28:632-638.

Klopfenstein, T. J., G. E. Erickson, and V. R. Bremer. 2008. BOARD-INVITED REVIEW: Use of distillers by-products in the beef cattle feeding industry. J. Anim. Sci. 86:1223-1231.

Korean Carcass Grading Standard. 2010. Bremer. 2008. National Livestock Co-operatives Federation, Seoul, Korea.

Lee, J. M., J. H. Choe, H. J. Jin, T. I. Kim, B. Y. Park, D. Y. Hwang, K. C. Koh, C. J. Kim, and K. S. Hwang. 2012. Effect 
of marbling score on carcass grade factors, physico-chemical and sensory traits of M. Longissimus Dorsi in Hanwoo. Korean J. Food Sci. Anim. 32:659-668.

Liu, KeShun. 2011. Chemical composition of distillers grains, a review. J. Agric. Food Chem. 59:1508-1526.

May, M. L., J. Quinn, N. DiLorenzo, and M. L. Galyean. 2010. Effects of roughage and wet distillers grains with solubles in steam-flaked corn-based substrates on feedlot cattle performance and carcass characteristics. In Proc. Plains Nutr. Council Spring Conf. AREC 10-57, Texas AgriLife Res. and Ext. Center, Amarillo, TX, USA. 107 p.

McDougall, E. I. 1948. Studies on ruminant saliva. I. The composition and output of sheep's saliva. Biochem. J. 43:99109.

NIAS (National Institute of Animal Science). 2012. Korean Feeding Standard for Hanwoo. 3rd Ed. Rural Development Administration, Jeonju, Korea.

Owens, F. N., D. S. Secrist, W. J. Hill, and D. R. Gill. 1998 Acidosis in cattle: A review. J. Anim. Sci. 76:275-286.

Quinn, M. J., M. L. May. N. DiLorenzo, C. H. Ponece, D. R. Smith, S. L. Parr, and M. L. Galyean. 2011. Effects of roughage source and distillers grain concentration on beef cattle finishing performance, carcass characteristics, and in vitro fermentation. J. Anim. Sci. 89:2631-2642.

Rouse, G. and A. Trenkle. 1980. Stillage from grain alcohol and a feed source for cattle. A. S. Leaflet R307. Iowa State Univ., Ames, IA, USA. pp. 1-2.

SAS Institute. 2002. SAS User's Guide: Statistics. Ver. 9.03 ed. Statistical Analysis Systems Institute Inc., Cary, NC, USA.

Scharf, B., J. A. Carroll, D. G. Riley, C. C. Chase, Jr., S. W. Coleman, D. H. Keisler, R. L. Weaber, and D. E. Spiers. 2010. Evaluation of physiological and blood serum differences in heat-tolerant (Romosinuano) and heat-susceptible (Angus) Bos taurus cattle during controlled heat challenge. J. Anim. Sci. 88:2321-2336.
Shurson, J. and S. Noll. 2005. Feed and Alternative Uses for DDGS. In: Proceeding of the 2005 Energy from Agriculture Conference, St. Louis, MO, USA. pp. 14-15.

Statistics Korea. http://kosis.kr/upsHtml/online/downSrvcFile.do? PUBCODE=JI\&FILE_NAME=/JI/LF14.pdf\&SEQ=7. Accessed July $1,2015$.

Stock, R. and T. Klopfenstein. 1982. Feeding value of distillers grains for ruminants. In: Feed and Fuel from Ethanol Production Symposium (Ed. R. A. Parsons). Northeast Regional Agric. Engineering Service Publ. 17. Ithaca, NY, USA.

Tilley, J. M. A. and A. R. Terry. 1963. A two stage technique for the in vitro digestion of forage crops. Grass Forage Sci. 18:104-111.

Van Soest, P. J. 1989. On the digestibility of bound $\mathrm{N}$ in distillers grains: A reanalysis. Proc. Cornell Nutrition Conf. Ithaca, NY, USA. 44:127-135.

Van Soest, P. J., J. B. Robertson, and B. A. Lewis. 1991. Methods of dietary fiber, neutral detergent fiber, and nonstarch polysaccharides in relation to animal nutrition. J. Dairy Sci. 74:3583-3597.

Waldo, G., Nuez Ortin, and Peiqiang Yu. 2009. Nutrient variation and availability of wheat DDGS, corn DDGS and blend DDGS from bioethanol plants. J. Sci. Food Agric. 89:1754-1761.

Waller, J., T. Klopfenstein, and M. Poos. 1980. Distillers feeds as protein sources for growing ruminants. J. Anim. Sci. 51:11541167.

Weiss, W. P., D. O. Ericson, G. M. Ericson, and G. R. Fisher. 1989. Barley distillers grains as a protein supplement for dairy cows. J. Dairy Sci. 72:980-987.

Xu, C. C., Y. Cai, J. G. Zhang, and M. Ogawa. 2007. Fermentation quality and nutritive value of a total mixed ration silage containing coffee grounds at ten or twenty percent of dry matter. J. Anim. Sci. 85:1024-1029. 